\title{
Cardiac performance in various stages of renal failure
}

\author{
S KENNETH PEHRSSON,^ RUNE JONASSON,† LARS-ERIC LINS $\ddagger$
}

From the Divisions of ${ }^{\star}$ Cardiology and $\ddagger N e p h r o l o g y$, Department of Medicine and the Department of fClinical Physiology, Karolinska Hospital, Stockholm, Sweden

SUMMARY Cardiac catheterisation was performed to evaluate cardiac function in 12 patients with various stages of renal failure. All patients were studied at rest and during supine exercise to subjective exhaustion. Eight patients had a normal arteriovenous oxygen difference at rest and during exercise whereas three had a low arteriovenous oxygen difference and one a high arteriovenous oxygen difference. Left ventricular stroke work did not increase normally at transition from rest to exercise in most patients with serum creatinine concentrations $>500 \mu \mathrm{mol} / \mathrm{l}$. The left ventricular end diastolic pressure was abnormally raised during exercise in all patients (range $20-42 \mathrm{~mm} \mathrm{Hg}$ ) and also at rest in most of them (range $8-36 \mathrm{~mm} \mathrm{Hg}$ ), indicating myocardial dysfunction. These observations suggest that patients have abnormal cardiac performance at a relatively early stage of renal failure.

Cardiovascular complications are the most frequent causes of death in uraemic patients, accounting for more than $40 \%$ of the total mortality. ${ }^{1-3}$ Congestive heart failure is common in end stage renal disease. Most published reports of cardiac performance in uraemic patients are based on non-invasive techniques, such as echocardiography, ${ }^{4-10}$ measurement of systolic time intervals, ${ }^{411-13}$ and radionuclide angiocardiography. ${ }^{14}$ Cardiac catheterisation, which yields more exact information on cardiac function, has been carried out in a few studies ${ }^{15-17}$ but not to our knowledge in the early stages of renal failure before dialysis is initiated.

The aim of the present study was to investigate cardiac performance as assessed at cardiac catheterisation at rest and during exercise in patients with various stages of renal failure.

\section{Patients and methods}

The study comprised six men and six women (mean age 46.8 (range 26-59) years). Table 1 shows some clinical data. The patients had various degrees of kidney function determined according to the serum creatinine concentrations. Three patients (cases 10, 11 , and 12) were undergoing maintenance haemodialysis. No patient had signs or a history of

Requests for reprints to Dr S Kenneth Pehrsson, Department of Medicine, Karolinska Hospital, S-104 01 Stockholm, Sweden.

Accepted for publication 24 July 1984 ischaemic heart disease, pericarditis, or valvar heart disease. Only one patient (case 8) had clinical signs of congestive heart failure, rales and dilated neck veins. None had electrolyte imbalance at the time of the study. Severe anaemia (haemoglobin concentration $<7.0 \mathrm{~g} / \mathrm{dl}$ ) was present in three patients. Seven were hypertensive with resting supine blood pressures $>150 / 90 \mathrm{~mm} \mathrm{Hg}$ or were receiving antihypertensive treatment. The diastolic pressure was recorded in Korotkoff phase 5. Informed consent was obtained and the study approved by the committee of ethics at the Karolinska Hospital.

All the patients underwent exercise stress tests sitting on a bicycle ergometer with an automatic device for increasing the continuous workload by $10 \mathrm{~W}$ each minute. ${ }^{18}$ A 12 lead electrocardiogram was recorded in the supine position before the test. A six lead chest electrocardiogram was used for monitoring with the indifferent electrode placed on the forehead. All the patients exercised to symptom limited maximum tolerance. The relative heart volume was determined on chest $x$ ray films in the erect position.

The patients were catheterised in the morning, in the fasting state, after premedication with $5 \mathrm{mg}$ diazepam intramuscularly. A Swan-Ganz thermodilution catheter (Edward Laboratories, Model 93-113-F) was inserted percutaneously under local anaesthesia into an antecubital vein and was advanced to the pulmonary artery. A radio-opaque Teflon catheter was introduced percutaneously into the right brachial artery and guided into the left ventricle. In two 
Table 1 Clinical and laboratory data

\begin{tabular}{|c|c|c|c|c|c|c|c|c|c|c|}
\hline $\begin{array}{l}\text { Case } \\
\text { No }\end{array}$ & $\begin{array}{l}\text { Sex/age } \\
(y r)\end{array}$ & $\begin{array}{l}B S A \\
\left(m^{2}\right)\end{array}$ & $\begin{array}{l}\text { Renal } \\
\text { disease }\end{array}$ & $\begin{array}{l}\text { Serum creatinine } \\
\text { concentration } \\
(\mu m o l / l)\end{array}$ & $\begin{array}{l}H b \\
\text { concentration } \\
(\mathrm{g} / \mathrm{d})\end{array}$ & $\begin{array}{l}\text { Blood } \\
\text { volume } \\
(l)\end{array}$ & $\begin{array}{l}\text { Relative } \\
\text { heart } \\
\text { volume } \\
\left(\mathrm{ml} / \mathrm{m}^{2}\right)\end{array}$ & $\begin{array}{l}\text { Blood } \\
\text { pressure }\end{array}$ & $\begin{array}{l}\text { ECG at rest/ } \\
\text { on exercise }\end{array}$ & Medication \\
\hline $\begin{array}{l}1 \\
2\end{array}$ & $\begin{array}{l}F / 54 \\
M / 44\end{array}$ & $\begin{array}{l}1.57 \\
1.82\end{array}$ & $\begin{array}{l}\text { CPN } \\
\text { CGN }\end{array}$ & $\begin{array}{l}400 \\
450\end{array}$ & $\begin{array}{l}12 \cdot 1 \\
11 \cdot 5\end{array}$ & $\begin{array}{l}3.5 \\
4.5\end{array}$ & $\begin{array}{l}320 \\
410\end{array}$ & $\begin{array}{l}\text { NT } \\
\text { HT }\end{array}$ & $\begin{array}{l}\mathbf{N} / \mathbf{N} \\
\mathbf{N} / \mathbf{N}\end{array}$ & \multirow{3}{*}{$\begin{array}{l}\text { Frusemide } 40 \mathrm{mg} \times 1 \\
\text { Alprenolol } 200 \mathrm{mg} \times 2 \\
\text { Hydralazine } 80 \mathrm{mg} \times 2 \\
\text { Metoprolol } 100 \mathrm{mg} \times 2 \\
\text { Frusemide } 40 \mathrm{mg} \times 1 \\
\text { Metroprolol } 100 \mathrm{mg} \times 2 \\
\text { Hydralazine } 25 \mathrm{mg} \times 3\end{array}$} \\
\hline 3 & M/35 & 1.99 & PK & 450 & $16 \cdot 0$ & 4.8 & 310 & HT & $\mathbf{N} / \mathbf{N}$ & \\
\hline 4 & M/55 & $2 \cdot 12$ & CGN & 500 & $11 \cdot 7$ & 5.6 & 450 & HT & LAFB/LAFB & \\
\hline $\begin{array}{l}5 \\
6\end{array}$ & $\begin{array}{l}F / 52 \\
F / 53\end{array}$ & $\begin{array}{l}1.52 \\
1.64\end{array}$ & $\begin{array}{l}\text { PK } \\
\text { RD }\end{array}$ & $\begin{array}{l}550 \\
670\end{array}$ & $\begin{array}{r}7.5 \\
10.3\end{array}$ & $\begin{array}{l}4 \cdot 4 \\
3 \cdot 3\end{array}$ & $\begin{array}{l}520 \\
490\end{array}$ & $\begin{array}{l}\text { NT } \\
\text { HT }\end{array}$ & $\begin{array}{l}\text { N/N } \\
\text { ST-T/ST-T }\end{array}$ & \multirow{6}{*}{$\begin{array}{l}\overline{\text { Alpenolol }} 200 \mathrm{mg} \times 1 \\
\text { Hydralazine } 15 \mathrm{mg} \times 3 \\
\text { Frusemide } 40 \mathrm{mg} \times 1 \\
\text { Metoprolol } 100 \mathrm{mg} \times 2 \\
\text { Hydralazine } 50 \mathrm{mg} \times 1 \\
\text { Frusemide } 40 \mathrm{mg} \times 2 \\
\text { Frusemide } 40 \mathrm{mg} \times 3 \\
\text { Digitoxin } 0.1 \mathrm{mg} \times 1 \\
\text { Frusemide } 80 \mathrm{mg} \times 2 \\
\text { Digitoxin } 0.1 \mathrm{mg} \times 1 \\
\text { Frusemide } 250 \mathrm{mg} \times 2 \\
\text { Hydralazine } 25 \mathrm{mg} \times 4 \\
\text { Digitoxin } 0.1 \mathrm{mg} \times 1 \\
\text { Frusemide } 250 \mathrm{mg} \times 3 \\
\text { Digitoxin } 0.1 \mathrm{mg} \times 1 \\
\text { Frusemide } 500 \mathrm{mg} \times 3\end{array}$} \\
\hline 7 & $M / 41$ & $2 \cdot 28$ & CGN & 800 & $13 \cdot 6$ & - & 400 & HT & $\mathbf{N} / \mathbf{N}$ & \\
\hline $\begin{array}{l}8 \\
9\end{array}$ & $\begin{array}{l}F / 53 \\
F / 46\end{array}$ & $\begin{array}{l}1.55 \\
1.45\end{array}$ & $\begin{array}{l}\text { PK } \\
\text { RD }\end{array}$ & $\begin{array}{r}950 \\
1000\end{array}$ & $\begin{array}{l}7.7 \\
7.5\end{array}$ & $\begin{array}{l}4 \cdot 0 \\
4.2\end{array}$ & $\begin{array}{l}420 \\
450\end{array}$ & $\begin{array}{l}\mathrm{NT} \\
\mathrm{NT}\end{array}$ & $\begin{array}{l}\text { N/N } \\
\text { ST-T/ST-T }\end{array}$ & \\
\hline 10 & $M / 42$ & 1.81 & $\mathrm{CGH}$ & 1245 (HD) & 6.4 & 5.8 & 640 & HT & LVH/LVH & \\
\hline 11 & $M / 26$ & 1.95 & CGN & 1440 (HD) & 6.8 & 5.9 & 710 & HT & LVH/LVH & \\
\hline 12 & $F / 59$ & 1.56 & PK & 900 (HD) & 6.8 & $4 \cdot 6$ & 425 & NT & ST-T/ST-T & \\
\hline
\end{tabular}

BSA, body surface area; CGN, chronic glomerulonephritis; CPN, chronic pyelonephritis; HD, haemodialysis; HT, hypertension; LAFB, left anterior fascicular block; LVH, left ventricular hypertrophy; N, normal; NT, normotension; PK, polycystic kidneys; RD, renal dysplasia; ST-T, non-specific ST-I changes

patients the catheter slipped out of the left ventricle during exercise. In these two patients the pulmonary capillary venous pressure or the pulmonary artery diastolic pressure was used as a measure of the left ventricular end diastolic pressure during exercise. The catheters were connected to electromechanical transducers (Siemens-Elema, EMT 34). The pressures were recorded on an ultraviolet recorder (ABEM, Ultralette 5651). Left ventricular pressure was also recorded on magnetic tape (Tandberg, Recorder Series 100) and subsequently processed in a computer (IBM 1800), which calculated haemodynamic indices such as aortic and left ventricular mean systolic pressures by planimetric integration during ejection. The mid-thorax was taken as the zero reference level of pressure.

\section{MEASUREMENTS OF CARDIAC PERFORMANCE}

Measurements were made with the patient supine $(a)$ at rest, $(b)$ with legs placed on the pedals $15 \mathrm{~cm}$ above the table, and during exercise, $(c)$ with a six minute period of steady state work at a low workload followed by $(d)$ a period of stepwise increases in workload $(10 \mathrm{~W}$ per minute) until symptom limited maximum tolerance was reached. Cardiac output was determined by the thermodilution technique; $5 \mathrm{ml}$ isotonic saline solution at $15^{\circ} \mathrm{C}$ was injected and output determined every 30 seconds during exercise. For technical reasons thermodilution was not used in one patient (case 6) and in another (case 9) during exercise. Car- diac output was also measured by the Fick method at rest and during steady state work to validate the thermodilution measurements. Comparisons between the thermodilution and Fick determinations showed good agreement $(r=0.88, p<0.01)$.

The total number of thermodilution determinations of cardiac output averaged 20 per patient. Together with the continuous recordings of left ventricular pressure, these measurements were used to calculate the stroke work index (SWI) and left ventricular power index (LVPI) according to the formulas: SWI $=($ LVMSP-LVEDP $) \times S V \times c / B S A \quad\left(\mathrm{~J} / \mathrm{beat} / \mathrm{m}^{2}\right.$ BSA), and LVPI $=S W I \times H R \times 1 / 60 / \mathrm{m}^{2} B S A$, where BSA is body surface area $\left(m^{2}\right), H R$ is heart rate (beats/min), LVMSP is left ventricular mean systolic pressure $(\mathrm{mm} \mathrm{Hg})$, LVEDP is left ventricular end diastolic pressure $(\mathrm{mm} \mathrm{Hg}), \mathrm{SV}$ is stroke volume $(\mathrm{ml})$, and $\mathrm{c}$ is constant $\left(1.33 \times 10^{-4}\right)$. The systemic vascular resistance (SVR) was calculated according to the formula: $S V R=(80(\mathrm{AOm}-\mathrm{RAm})) / \mathrm{Q}$ dyn s cm $\mathrm{cm}^{-5}$, where AOm and RAm are aortic (measured at rest before entering the left ventricle) and right atrial mean pressures ( $\mathrm{mm} \mathrm{Hg}$ ) and $Q$ is cardiac output (1/min). Pulmonary vascular resistance was calculated at rest according to the formula: $\mathrm{PVR}=(80(\mathrm{PAm}-\mathrm{PVCm})) / \mathrm{Q}$ where $\mathrm{PAm}$ and $\mathrm{PVCm}$ are pulmonary artery and pulmonary venous capillary mean pressure $(\mathrm{mm} \mathrm{Hg})$. This formula was used for all patients except for that in case 3 , in whom left ventricular end diastolic pressure was used as a meas- 
Table 2 Maximum workload and heart rates in sitting and supine positions

\begin{tabular}{|c|c|c|c|c|c|c|}
\hline \multirow{2}{*}{$\begin{array}{l}\text { Case } \\
\text { No }\end{array}$} & \multicolumn{2}{|c|}{ Heart rate sitting (beats/min) } & \multirow{2}{*}{$\begin{array}{l}\text { Maximum } \\
\text { workload } \\
\text { (W) }\end{array}$} & \multicolumn{2}{|c|}{ Heart rate supine (beats/min) } & \multirow{2}{*}{$\begin{array}{l}\text { Maximum } \\
\text { workload } \\
\text { (W) }\end{array}$} \\
\hline & At rest & $\begin{array}{l}\text { At maximum } \\
\text { workload }\end{array}$ & & At rest & $\begin{array}{l}\text { At maximum } \\
\text { workload }\end{array}$ & \\
\hline $\begin{array}{r}1 \\
2 \\
3 \\
4 \\
5 \\
6 \\
7 \\
8 \\
9 \\
10 \\
11 \\
12\end{array}$ & $\begin{array}{l}70 \\
64 \\
59 \\
65 \\
70 \\
70 \\
70 \\
68 \\
66 \\
90 \\
75 \\
80\end{array}$ & $\begin{array}{l}146 \\
135 \\
132 \\
152 \\
144 \\
115 \\
116 \\
156 \\
160 \\
108 \\
104 \\
128\end{array}$ & $\begin{array}{r}70 \\
190 \\
160 \\
140 \\
90 \\
90 \\
200 \\
90 \\
100 \\
40 \\
60 \\
50\end{array}$ & $\begin{array}{l}66 \\
77 \\
95 \\
70 \\
77 \\
76 \\
62 \\
70 \\
59 \\
92 \\
76 \\
81\end{array}$ & $\begin{array}{c}114 \\
146 \\
120 \\
115 \\
140 \\
\overline{105} \\
130 \\
\overline{100} \\
95 \\
112\end{array}$ & $\begin{array}{r}50 \\
100 \\
100 \\
100 \\
60 \\
-100 \\
70 \\
-15 \\
60 \\
20\end{array}$ \\
\hline
\end{tabular}

ure of PVCm. During exercise left ventricular end diastolic pressure or pulmonary artery diastolic pressure was used as a measure of PVCm.

Blood volume was determined with the alveolar carbon monoxide method ${ }^{19}$ and serum creatinine concentration was measured as recommended by Taussky. ${ }^{20}$

Results are given as mean with standard deviation (SD) or with range. In statistical analysis of the data Student's $t$ test for non-paired observations and linear regression analysis were used.

\section{Results}

Table 1 shows the individual values for haemoglobin concentration, blood volume, and relative heart volume. The maximum workload and heart rate at rest and at maximum workload sitting and supine is given for each patient in Table 2. Dyspnoea or leg fatigue or both were the most common reasons for stopping the test. No patient complained of chest pain during exercise. The electrocardiographic pattern at rest did not alter during exercise. Table 3 shows the individual haemodynamic data.

Eight patients, including the three undergoing maintenance haemodialysis, had a normal arteriovenous oxygen difference, one patient (case 3 ) had a high value both at rest and during exercise (arteriovenous oxygen difference 54 and $118 \mathrm{ml} / \mathrm{l}$ respectively), whereas three patients (cases 2, 5, and 9) had a low value with a high cardiac output in relation to oxygen uptake. The arteriovenous oxygen difference correlated with the haemoglobin concentration $(r=0.68$, $p<0.05$ ). Thus those patients with the lowest haemoglobin concentrations had a smaller arteriovenous oxygen difference than the others. Resting cardiac output was higher in the three patients undergoing maintenance haemodialysis (cases 10,11 , and 12) than in the three patients with the lowest serum creatinine concentrations (cases 1,2 , and 3) $\left(7.6 v 5.51 / \mathrm{min}^{-1}\right)$, but the difference was not significant. The resting cardiac output did not correlate with the haemoglobin concentration.

Left ventricular end diastolic pressure was raised both at rest (range 8-36 $\mathrm{mm} \mathrm{Hg}$ ) and during exercise (range $20-42 \mathrm{~mm} \mathrm{Hg}$ ) in most patients. The value at rest inversely correlated with the haemoglobin concentration $(r=-0.65, p<0.05)$ - that is, the highest values were recorded in those with the lowest haemoglobin concentrations.

There was no correlation between serum creatinine concentrations and left ventricular end diastolic pressure at rest. Systemic vascular resistance and pulmonary vascular resistance were within normal limits (Table 3).

Left ventricular function curves were constructed for three groups, stratified according to serum creatinine concentrations (group 1, the three patients with concentrations $<500 \mu \mathrm{mol} / \mathrm{l}$; group 2 , the six patients with concentrations $500-1000 \mu \mathrm{mol} / \mathrm{l}$, and group 3, the three patients undergoing maintenance haemodialysis), by plotting means for stroke work index and left ventricular pressure index against the corresponding means for left ventricular end diastolic pressure at rest, with legs elevated, during steady state exercise, and at maximum workload (Figure $a$ ). The relation between stroke work index and left ventricular end diastolic pressure was normal for patients in group 1, but for those in groups 2 and 3 left ventricular end diastolic pressure was significantly raised with exercise. Left ventricular end diastolic pressure at rest did not differ significantly between the three groups. Stroke work index remained constant or even fell in groups 2 and 3 during exercise. The relation between left ventricular pressure index and left ventricular end diastolic pressure in group 2 and more notably for those in group 3 indicated the poor heart rate response to work. Grouping the patients according to blood pressure at rest (normotensive or hypertensive) showed no significant intergroup difference with respect to stroke work index or left ventricular end diastolic pressure (Figure $b$ ). 
Table 3 Haemodymamic measurements at rest and during steady state workloads

\begin{tabular}{|c|c|c|c|c|c|c|c|c|c|c|}
\hline $\begin{array}{l}\text { Case } \\
\text { No }\end{array}$ & $\begin{array}{l}\text { Workload } \\
(W)\end{array}$ & $\begin{array}{l}\text { Cardiac output } \\
\text { (Fick method) } \\
\text { (l/min) }\end{array}$ & $\begin{array}{l}S V \\
(m l)\end{array}$ & $\begin{array}{l}\text { HR } \\
\text { (beats/min) }\end{array}$ & $\begin{array}{l}A V D \\
(m l / l)\end{array}$ & $\begin{array}{l}\text { Oxygen } \\
\text { uptake } \\
\text { (ml/min) }\end{array}$ & $\begin{array}{l}\text { SVR } \\
\left.\text { (dyn s } \mathrm{cm}^{-s}\right)\end{array}$ & $\begin{array}{l}P V R \\
(\text { dyn s cm}\end{array}$ & $\begin{array}{l}\text { SWI } \\
(\mathcal{G} / \text { beat per } \\
\left.m^{2} B S A\right)\end{array}$ & $\begin{array}{ll}L V P I & \text { Mean } R A \\
\left(W / m^{2} B S A\right) & \begin{array}{l}\text { pressure } \\
\text { (mom } H g)\end{array}\end{array}$ \\
\hline
\end{tabular}

\begin{tabular}{|c|c|c|c|c|c|c|c|c|c|c|c|}
\hline $\begin{array}{c}1 \\
2 \\
3 \\
4 \\
5 \\
6 \\
7 \\
8 \\
9 \\
10\end{array}$ & $\begin{array}{l}\left\{\begin{array}{l}\text { Rest } \\
20\end{array}\right. \\
\left\{\begin{array}{l}\text { Rest } \\
80\end{array}\right. \\
\left\{\begin{array}{l}\text { Rest } \\
70\end{array}\right. \\
\left\{\begin{array}{l}\text { Rest } \\
60\end{array}\right. \\
\left\{\begin{array}{l}\text { Rest } \\
30\end{array}\right. \\
\left\{\begin{array}{l}\text { Rest } \\
30\end{array}\right. \\
\left\{\begin{array}{l}\text { Rest } \\
40\end{array}\right. \\
\left\{\begin{array}{l}\text { Rest } \\
30\end{array}\right. \\
\left\{\begin{array}{l}\text { Rest } \\
30 \\
\text { Rest } \\
10\end{array}\right. \\
\left\{\begin{array}{l}\text { Rest } \\
15\end{array}\right. \\
\left\{\begin{array}{l}\text { Rest } \\
15\end{array}\right.\end{array}$ & $\begin{array}{c}4.5 \\
6.2 \\
8.0 \\
16.4 \\
4.1 \\
9.3 \\
5.2 \\
11.1 \\
7.2 \\
12.7 \\
5.0 \\
9.8 \\
6.1 \\
9.9 \\
4.0 \\
8.4 \\
5.7 \\
11.9 \\
6.8 \\
(10.81) \\
9.7 \\
10.7 \\
6.3 \\
8.6\end{array}$ & $\begin{array}{c}68 \\
63 \\
104 \\
139 \\
43 \\
82 \\
74 \\
102 \\
94 \\
98 \\
66 \\
83 \\
98 \\
111 \\
57 \\
73 \\
97 \\
105 \\
74 \\
(104)^{\star} \\
128 \\
123 \\
78 \\
72\end{array}$ & $\begin{array}{r}66 \\
99 \\
77 \\
118 \\
95 \\
113 \\
70 \\
109 \\
77 \\
130 \\
76 \\
118 \\
62 \\
89 \\
70 \\
115 \\
59 \\
113 \\
92 \\
103 \\
76 \\
87 \\
81 \\
120\end{array}$ & $\begin{array}{r}43 \\
79 \\
30 \\
78 \\
54 \\
118 \\
45 \\
94 \\
29 \\
56 \\
45 \\
64 \\
46 \\
91 \\
46 \\
63 \\
30 \\
51 \\
38 \\
\\
35 \\
49 \\
31 \\
57\end{array}$ & $\begin{array}{r}193 \\
489 \\
240 \\
1276 \\
223 \\
1104 \\
235 \\
1042 \\
206 \\
704 \\
228 \\
626 \\
280 \\
896 \\
185 \\
535 \\
172 \\
608 \\
256 \\
\\
333 \\
521 \\
197 \\
492\end{array}$ & $\begin{array}{r}1742 \\
1300 \\
2107 \\
2353 \\
1311 \\
1872 \\
944 \\
2300 \\
1574 \\
1459 \\
1072 \\
1194\end{array}$ & $\begin{array}{r}124 \\
103 \\
133 \\
63 \\
136 \\
77 \\
92 \\
94 \\
44 \\
50 \\
112 \\
82 \\
92 \\
121 \\
80 \\
114 \\
42 \\
54 \\
153 \\
91 \\
82 \\
114 \\
121\end{array}$ & $\begin{array}{l}0.55 \\
0.63 \\
1.48 \\
1.75 \\
0.47 \\
0.94 \\
0.96 \\
0.97 \\
1.50 \\
1.38 \\
- \\
0.47 \\
0.52 \\
0.82 \\
0.84 \\
1.29 \\
0.65 \\
0.87 \\
1.47 \\
1.32 \\
0.80 \\
0.78\end{array}$ & $\begin{array}{l}0.63 \\
1.04 \\
1.90 \\
3.65 \\
0.75 \\
1.73 \\
1.01 \\
1.48 \\
1.50 \\
2.74 \\
- \\
0.49 \\
0.77 \\
0.84 \\
1.43 \\
1.33 \\
0 \\
0.85 \\
1.40 \\
1.89 \\
1.95 \\
1.18 \\
1.30\end{array}$ & $\begin{array}{r}6 \\
4 \\
6 \\
8 \\
4 \\
\\
8 \\
15 \\
10 \\
16 \\
3 \\
7\end{array}$ \\
\hline
\end{tabular}

$\star$ Determined by thermodilution. + Recorded $10 \mathrm{~min}$ after exercise. SV, stroke volume; HR, heart rate; AVD, arteriovenous oxygen difference; SVR ${ }^{6}$ systemic vascular resistance; PVR, pulmonary vascular resistance, SWI, stroke work index; LVPI, left ventricular power index, RA, right atrial; PCV, pulmonary çapillary venous pressure; $M$, mean; $S$, systolic; $D$, diastolic; $E D$, end diastolic.

\section{Discussion}

The comparisons in this study were made between patients in various stages of renal failure including three who were undergoing maintenance haemo-

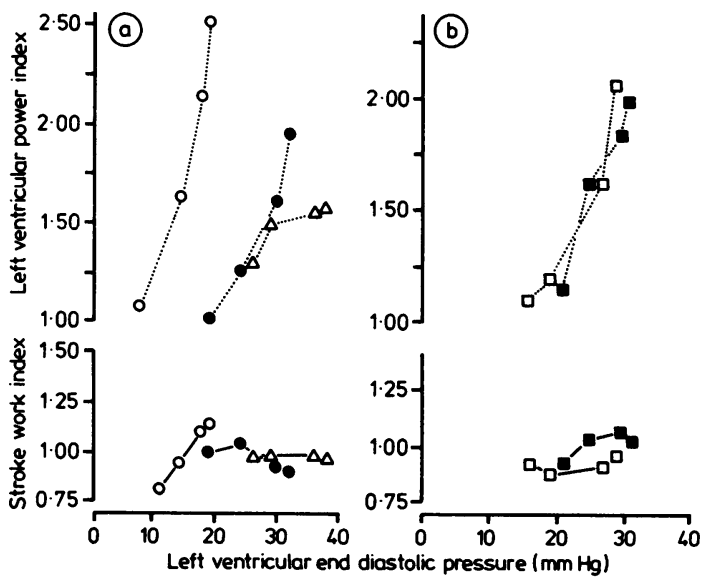

Figure Relation of left ventricular power index and stroke work index to left ventricular end diastolic pressure $(a)$ in three

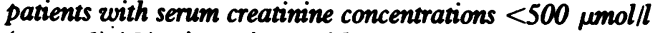
(group 1) (O), six patients with concentrations of 500-1000 rmolll (group 2) (O), and three patients undergoing maintenance haemodialysis ( $\triangle$; ; and $(b)$ in five normotensive $(\square)$ and seven hypertensive ( $\square$ ) patients. dialysis. The series of patients thus represented a heterogeneous group, which was also reflected by their individual differences in cardiac performance. The common feature was that all patients had abnormal renal function and when stratified according to serum creatinine concentrations had increasing left ventricular dysfunction on exercise in relation to decreasing renal function.

The three patients with serum creatinine concentrations $<500 \mu \mathrm{mol} / \mathrm{l}$ (group 1) had essentially normal left ventricular function, and the electrocardiographic patterns at rest and in response to exercise were normal. Thus myocardial disease was not apparently present in the earliest stages of renal failure. The six patients with serum creatinine concentrations in the range $500-1000 \mu \mathrm{mol} / 1$ (group 2) and the three patients undergoing haemodialysis (group 3 ), on the other hand, clearly had abnormal left ventricular function with increased left ventricular end diastolic pressure and an inability to achieve the increase in stroke work index during exercise that would normally occur (Figure $a$ ). ${ }^{21}$ These results may thus indicate an increased stiffness of the ventricular wall and diminished systolic contractile function in most patients with a serum creatinine concentration $>500 \mu \mathrm{mol} / \mathrm{l}$. Similar results with abnormal contractile indices associated with increased left ventricular end diastolic pressure have previously been observed in patients undergoing long term haemodialysis. ${ }^{15} 16$ 


\begin{tabular}{|c|c|c|c|c|c|c|c|c|c|c|c|c|c|}
\hline \multicolumn{13}{|c|}{ Pressures ( $\mathrm{mm} H \mathrm{Hg}$ ) } & \multirow{3}{*}{$\begin{array}{l}\text { Systolic } \\
\text { pressure } \\
\times \text { heart rate }\end{array}$} \\
\hline \multicolumn{3}{|c|}{ Right ventriculart } & \multicolumn{3}{|c|}{ Pulmonary artery } & \multirow{2}{*}{$\begin{array}{l}\text { Mean } \\
P C V\end{array}$} & \multicolumn{3}{|c|}{ Left ventricular } & \multicolumn{3}{|c|}{ Aorta } & \\
\hline$S$ & $D$ & $E D$ & $S$ & $D$ & $M$ & & $S$ & $D$ & $E D$ & $S$ & $D$ & $M$ & \\
\hline & & & $\begin{array}{l}24 \\
38\end{array}$ & $\begin{array}{l}10 \\
19\end{array}$ & $\begin{array}{l}16 \\
28\end{array}$ & 9 & $\begin{array}{l}136 \\
165\end{array}$ & $\begin{array}{l}6 \\
6\end{array}$ & $\begin{array}{l}10 \\
20\end{array}$ & 136 & 82 & 104 & $\begin{array}{r}8976 \\
16335\end{array}$ \\
\hline 22 & 5 & 14 & $\begin{array}{l}21 \\
49\end{array}$ & $\begin{array}{r}9 \\
23\end{array}$ & $\begin{array}{l}15 \\
33\end{array}$ & 8 & $\begin{array}{l}176 \\
220\end{array}$ & $\begin{array}{l}8 \\
8\end{array}$ & $\begin{array}{l}14 \\
20\end{array}$ & 176 & 104 & 136 & $\begin{array}{l}13552 \\
25960\end{array}$ \\
\hline 23 & 3 & 5 & $\begin{array}{l}23 \\
38\end{array}$ & $\begin{array}{r}5 \\
17\end{array}$ & $\begin{array}{l}15 \\
26\end{array}$ & & 138 & 7 & 8 & $\begin{array}{l}138 \\
140\end{array}$ & $\begin{array}{l}90 \\
84\end{array}$ & $\begin{array}{l}112 \\
110\end{array}$ & $\begin{array}{l}13110 \\
15820\end{array}$ \\
\hline 55 & 5 & 15 & $\begin{array}{l}28 \\
57\end{array}$ & $\begin{array}{l}18 \\
32\end{array}$ & $\begin{array}{l}22 \\
48\end{array}$ & 16 & $\begin{array}{l}218 \\
196\end{array}$ & $\begin{array}{r}6 \\
12\end{array}$ & $\begin{array}{l}24 \\
41\end{array}$ & 218 & 120 & 161 & $\begin{array}{l}15260 \\
21364\end{array}$ \\
\hline 36 & 4 & 10 & $\begin{array}{l}30 \\
47\end{array}$ & $\begin{array}{l}14 \\
28\end{array}$ & $\begin{array}{l}19 \\
38\end{array}$ & 15 & $\begin{array}{l}182 \\
226\end{array}$ & $\begin{array}{l}8 \\
8\end{array}$ & $\begin{array}{l}22 \\
37\end{array}$ & 182 & 94 & 128 & $\begin{array}{l}14014 \\
29380\end{array}$ \\
\hline 31 & 2 & 8 & $\begin{array}{l}26 \\
37 \\
23 \\
37\end{array}$ & $\begin{array}{l}10 \\
13 \\
13 \\
17\end{array}$ & $\begin{array}{l}16 \\
22 \\
17 \\
30\end{array}$ & $\begin{array}{r}9 \\
25 \\
10\end{array}$ & $\begin{array}{l}180 \\
105 \\
148\end{array}$ & $\begin{array}{l}0 \\
4 \\
9\end{array}$ & $\begin{array}{l}16 \\
13 \\
30\end{array}$ & $\begin{array}{l}180 \\
214 \\
105\end{array}$ & $\begin{array}{r}84 \\
100 \\
61\end{array}$ & $\begin{array}{r}120 \\
148 \\
79\end{array}$ & $\begin{array}{r}13680 \\
25252 \\
6510 \\
13172\end{array}$ \\
\hline 32 & 5 & 13 & $\begin{array}{l}25 \\
53\end{array}$ & $\begin{array}{l}15 \\
28\end{array}$ & $\begin{array}{l}19 \\
40\end{array}$ & 15 & $\begin{array}{l}176 \\
200\end{array}$ & $\begin{array}{r}10 \\
0\end{array}$ & $\begin{array}{l}20 \\
24\end{array}$ & 176 & 94 & 126 & $\begin{array}{l}12320 \\
22770\end{array}$ \\
\hline 32 & 0 & 4 & $\begin{array}{l}20 \\
40\end{array}$ & $\begin{array}{r}9 \\
17\end{array}$ & $\begin{array}{l}14 \\
28\end{array}$ & 11 & $\begin{array}{l}152 \\
184\end{array}$ & $\begin{array}{l}6 \\
0\end{array}$ & $\begin{array}{l}14 \\
24\end{array}$ & 152 & 92 & 116 & $\begin{array}{r}8968 \\
20792\end{array}$ \\
\hline 45 & 2 & 8 & $\begin{array}{l}50 \\
76\end{array}$ & $\begin{array}{l}24 \\
36\end{array}$ & $\begin{array}{l}38 \\
52\end{array}$ & 25 & $\begin{array}{l}168 \\
204\end{array}$ & $\begin{array}{l}24 \\
20\end{array}$ & $\begin{array}{l}36 \\
42\end{array}$ & 168 & 100 & 130 & 15456 \\
\hline 46 & 6 & 14 & $\begin{array}{l}44 \\
59\end{array}$ & 23 & $\begin{array}{l}33 \\
46\end{array}$ & 24 & $\begin{array}{l}186 \\
188\end{array}$ & $\begin{array}{l}16 \\
15\end{array}$ & $\begin{array}{l}28 \\
35\end{array}$ & 180 & 108 & 140 & $\begin{array}{l}13680 \\
16356\end{array}$ \\
\hline 27 & 2 & 7 & $\begin{array}{l}27 \\
71\end{array}$ & $\begin{array}{l}12 \\
34\end{array}$ & $\begin{array}{l}18 \\
49\end{array}$ & 9 & $\begin{array}{l}146 \\
180\end{array}$ & $\begin{array}{r}8 \\
16\end{array}$ & $\begin{array}{l}15 \\
36\end{array}$ & 146 & 70 & 99 & $\begin{array}{l}11826 \\
21600\end{array}$ \\
\hline
\end{tabular}

Abnormal cardiac performance in end stage renal failure may result from a variety of mechamisms, such as hypertension, hypervolaemia, pericarditis with or without pericardial effusion, anaemia, and electrolyte and metabolic disturbances. Hypertension is commonly associated with renal failure, and volume overload has been suggested as the predominant cause of renal hypertension. ${ }^{22-25}$ In possible contradiction to this hypothesis, however, is the fact that uraemic patients are usually hypertensive at an early stage of renal failure, when as a rule the blood volume is normal or even low. ${ }^{26} 27$ Hypertension also plays an important role in the pathogensis of heart failure in uraemic patients. ${ }^{16}$ But the normotensive and the hypertensive patients in the present study showed similar abnormal left ventricular function at different stages of renal failure (Figure $b$ ). This comparison suggested that uraemic heart failure develops irrespective of hypertension.

Accelerated atherosclerosis occurs in patients undergoing long term haemodialysis, and also a high mortality from arteriosclerotic complications in chronic renal failure has been reported. ${ }^{28}$ In subsequent studies, however, the incidence of cardiovascular deaths from atherosclerosis was lower than previously stated and, in fact, not more common than in the total population..$^{29-31}$

In the present series of patients the absence of chest pain and of electrocardiographic characteristics of ischaemic heart disease during exercise indicated that advanced coronary atherosclerosis had not developed.
The severe anaemia in some of the patients could have been expected to unmask any significant coronary artery disease.

High output congestive heart failure resulting from the arteriovenous fistula in patients undergoing maintenance dialysis has been reported by several authors. ${ }^{32-34}$ Resting cardiac output up to $10 \mathrm{l} / \mathrm{min}$, which falls substantially during temporary occlusion of the shunt, was found in such patients. The relatively high resting cardiac output in three of the present patients undergoing maintenance haemodialysis did not, however, differ significantly from that in the non-dialysed patients. The high values probably also reflect the chronic anaemia present in most of these patients. In this study the haemoglobin concentration was found to be correlated with the left ventricular end diastolic pressure and the arteriovenous oxygen difference. Nevertheless, the effect of isolated severe chronic anaemia on cardiac function has been reported to be minimal, ${ }^{35}$ with no influence on left ventricular end diastolic pressure. ${ }^{36}$ Furthermore, the cardiac output at rest is usually not increased until the haemoglobin concentration is $<7.0 \mathrm{~g} / \mathrm{d} .{ }^{36}$ The abnormal left ventricular function in the present patients in group 2 could not, however, be explained by severe anaemia, an arteriovenous shunt, or haemodialysis. We, therefore, consider that anaemia and the presence of arteriovenous shunts-for example-should be regarded as factors potentiating or unmasking the underlying myocardial disease rather than as causal agents in their own right. 
A specific uraemic cardiomyopathy has been postulated, 14161737 but documentation of the condition has been hampered by all the abovementioned factors that may underlie abnormal cardiac performance. The findings in the present series of patients are not inconsistent with the concept of a specific uraemic heart disease, since in most patients with abnormal cardiac performance the aetiology of the cardiac dysfunction was otherwise obscure. As early as 1944 Raab suggested that a specific myocardial toxin may be present in uraemia and constitute the primary cause of uraemic heart disease. ${ }^{38}$ Many substances can accumulate in the body in uraemia, and some of them may act as toxins. Among the chemicals that could lead to cardiac damage and dysfunction, no specific myocardial toxin has yet been identified. Excess parathyroid hormone, however, has been suggested from clinical ${ }^{3940}$ and experimental ${ }^{41}$ observations to have a significant effect on the myocardium, causing ectopic calcifications. Parathyroidectomy has been reported to improve cardiac function in patients with end stage renal failure. ${ }^{40}$ Other agents that may play an important role in the pathogenesis of uraemic heart failure are certain trace elements. These elements were found in appreciably increased concentrations in the myocardium of uraemic patients. ${ }^{42}$

An accumulation of toxins would be consistent with the progressive deterioration in cardiac performance in the present series of patients. The removal of such toxins after renal transplantation would accordingly be expected to result in improved cardiac performance and this has recently been reported. ${ }^{43}$

In conclusion, the observations in our study indicate that uraemic heart failure is a result of several different pathogenic factors and arises at a relatively early stage of renal failure.

\section{References}

1 Wing AJ, Brunner FP, Brynger $\mathrm{H}$, et al. Combined report on regular dialysis and transplantation in Europe, VIII, 1977. Proc Eur Dial Transplant Assoc 1978; 15: 4-76.

2 Lazarus JM, Lowrie EG, Hampers CL, Merrill JP. Cardiovascular disease in uremic patients on hemodialysis. Kidney Int 1975; 7 (suppl 2): 167-75.

3 Scharf S, Wexler J, Longnecker RE, Blalufox MD. Cardiovascular disease in patients on chronic hemodialytic therapy. Prog Cardiovasc Dis 1980; 22: 343-56.

4 Lewis BS, Milne FJ, Goldberg B. Left ventricular function in chronic renal failure. $\mathrm{Br}$ Heart $\mathcal{f} 1976$; 38: 1229 39.

5 Cohen MV, Diaz P, Scheuer J. Echocardiographic assessment of left ventricular function in patients with chronic uremia. Clin Nephrol 1979; 12: 156-62.

6 D'Cruz IA, Bhatt GR, Cohen HC, Glick G. Echocardiographic detection of cardiac involvement in patients with chronic renal failure. Arch Intern Med 1979; 138: $720-4$.

7 Riley SM Jr, Blackstone EH, Sterling WA, Diethelm AG. Echocardiographic assessment of cardiac performance in patients with arteriovenous fistulas. Surgery Gynecol Obstet 1978; 146: 203-8.

8 Miach PJ, Dawborn JK, Louis WJ, McDonald IG. Left ventricular function in uremia: echocardiographic assessment in patients on maintenance dialysis. Clin Nephrol 1981; 15: 259-63.

9 Abbasi AS, Slaughter JC, Allen MW. Asymmetric septal hypertrophy in patients on long-term hemodialysis. Chest 1978; 74: 548-51.

10 Ikäheimo M, Huttunen K, Takkunen J. Cardiac effects of chronic renal failure and hemodialysis treatment hypertensive versus normotensive patients. Br Heart $\mathcal{f}$ 1981; 45: 710-6.

11 Bornstein A, Zambrano SS, Morrison RS, Spodick DH. Cardiac effects of hemodialysis: noninvasive monitoring by systolic time intervals. Am $\mathcal{F}$ Med Sci 1975; 269: 18992.

12 Dongradi G, Dubois D, Bécart J, Coy JL, Fendleu JP. Function myocardique de l'hémodialysé chronique. Evaluation par la mesure des intervalles de temps systoliques. Nouv Presse Med 1977; 6: 2039-42.

13 Ireland MA, Mehta BR, Shiu MF. Acute effects of haemodialysis on left heart dimensions and left ventricular function: an echocardiographic study. Nephron 1981; 29: 73-9.

14 Hung J, Harris PJ, Uren RF, Tiller DJ, Kelly DT. Uremic cardiomyopathy - effect of hemodialysis on left ventricular function in end-stage renal failure. $N$ Engl f Med 1980; 302: 547-51.

15 Drüeke T, Le Pailleur C, Meilhac B, et al. Congestive cardiomyopathy in uraemic patients on long-term haemodialysis. Br Med f 1977; 1: 350-3.

16 Capelli JP, Kasparian H. Cardiac work demands and left ventricular function in end-stage renal disease. Ann Intern Med 1977; 86: 261-7.

17 Drtieke T, Le Pailleur C, Sigal-Saglier M, Zingraff J, Crosnier J, Di Matté J. Left ventricular function in hemodialyzed patients with cardiomegaly. Nephron 1981; 28: 80-7.

18 Aström H, Joknsson B. Design of exercise test with special reference to heart patients. $B r$ Hear $\mathcal{F}$ 1976; 38: 289-96.

19 Sjöstrand T. A method for the determination of the total haemoglobin content of the body. Acta Physiol Scand 1948; 16: 211-31.

20 Taussky AHH. Standard methods of clinical chemistry. vol 3. New York and London: Academic Press, 1961.

21 Ekelund LG, Holmgren A. Central hemodynamics during exercise. Circ Res 1967; 20 (suppl I): 33-43.

22 Dustan HP, Page IH. Some factors in renal and renoprival hypertension. F Lab Clin Med 1964; 64: 948-59.

23 Vertes V, Cangiano JL, Berman LB, Gould A. Hypertension in end-stage renal disease. N Engl f Med 1969; 280: 978-81.

24 De Planque BA, Mulder E, Mees EJD. The behaviour of blood and extracellular volume in hypertensive patients with renal insufficiency. Acta Med Scand 1969; 186: 7581. 
25 Lazarus JM, Hampers CL, Merrill JP. Hypertension in chronic renal failure. Treatment with hemodialysis and nephrectomy. Arch Intern Med 1974; 133: 1059-66.

26 Hull AR, Long DL, Prati RC, Pettinger WA, Parker TF. The control of hypertension in patients undergoing regular maintenance hemodialysis. Kidney Int 1975; 7 (suppl 2): 184-7.

27 McGrath BP, Ledingham JGG. Renin, blood volume and response to saralasin in patients on chronic haemodialysis: evidence against volume and renin "dependent" hypertension. Clin Sci Mol Med 1978; 54: 305-12.

28 Lindner A, Charra B, Sherrard DJ, Scribner BH. Accelerated atherosclerosis in prolonged maintenance hemodialysis. N Engl f Med 1974; 290: 697-701.

29 Burke JF Jr, Francos GC, Moore LL, Yon Cho S, Lasker N. Accelerated atherosclerosis in chronic dialysis patients - another look. Nephron 1978; 21: 181-5.

30 Nicholls AJ, Catto GRD, Edward N, Engeset J, Macleod $M$. Accelerated atherosclerosis in long-term dialysis and renal-transplant patients: fact or fiction? Lancet 1980; i: 276-8.

31 Clyne N, Lins LE, Pehrsson SK. Heart disease in uremia [Abstract]. Blood Purification 1983; 1: 102.

32 Ahearn DJ, Maher JF. Heart failure as a complication of hemodialysis arteriovenous fistula. Ann Intern Med 1972; 77: 201-4.

33 Anderson CB, Groce MA. Banding of arteriovenous dialysis fistulas to correct high-output cardiac failure. Surgery 1975; 78: 552-4.

34 Anderson CB, Codd JR, Graff RA, Groce MA, Hartner HR, Newton WT. Cardiac failure and upper extremity arteriovenous dialysis fistulas. Arch Intern Med 1976; 136: 292-7.

35 Warrier ER, Balakrishnan KG, Sankaran K, Gupta GD. Systolic time intervals in chronic severe anaemia and effect of diuretic and digitalis. Br Heart f 1981; 46: 80-3.

36 Varat MA, Adolph RJ, Fowler NO. Cardiovascular effects of anemia. Am Heart $\mathcal{F}$ 1972; 83: 415-26.

37 Prosser D, Parsons V. The case for a specific uraemic myocardiopathy. Nephron 1975; 15: 4-7.

38 Raab W. Cardiotoxic substances in the blood and heart muscle in uremia. $f$ Lab Clin Med 1944; 29: 715-34.

39 Massry SG, Goldstein DA. The search for uremic toxin(s) "x"- "x"= PTH. Clin Nephrol 1979; 11: 181-9.

40 Drüeke T, Fauchet M, Fleury J, et al. Effect of parathyroidectomy on left ventricular function in hemodialysis patients. Lancet 1980; i: 112-4.

41 Ejerblad S. Uraemic myocardial disease. An experimental study with special reference to the effect of parathyroidectomy. Acta Chir Scand 1979; 145: 345-53.

42 Pehrsson SK, Lins LE. The role of trace elements in uremic heart failure. Nephron 1983; 34: 93-8.

43 Lai KN, Barnden L, Mathew TH. Effect of renal transplantation on left ventricular function in hemodialysis patients. Clin Nephrol 1982; 18: 74-8. 